\title{
The status and ecology of the last wild population of Madagascar Pochard Aythya innotata
}

\author{
ANDREW J. BAMFORD, THE SEING SAM, FELIX RAZAFINDRAJAO, \\ HANNAH ROBSON, LANCE G. WOOLAVER and \\ LILY ARISON RENÉ de ROLAND
}

\section{Summary}

One of the rarest birds in the world, the Madagascar Pochard Aythya innotata was thought to be extinct until a small population was found in 2006. Little is known about this diving duck as it had not been studied prior to its decline and disappearance. Its rediscovery provided the opportunity to study this species in the wild for the first time and to assess the viability of this last remaining population. The population is small, fluctuating around 25 individuals, and mainly utilises two small volcanic lakes in the far north of Madagascar. Nesting occurs on only one of these lakes, Matsaborimena. Nest success ( $76 \%$ in 2007-2008) and hatching success ( $89 \%$ in 2007-2008) are both comparable to other Aythya species, but fledging success (4\% in 2011-2012) is extremely low. Duckling mortality rates peak between 14 and 21 days old. We propose that starvation is the major cause of duckling mortality. Examination of faecal samples and stable isotope analysis of feathers and potential food items provide evidence that adult pochards are insectivorous, favouring caddis fly larvae. Macroinvertebrate density in the benthos of Matsaborimena is low. Adults spend $38 \%$ of daylight hours foraging, mainly in the shallowest water. However Matsaborimena is steep-sided and has no areas shallow enough for diving ducklings to feed. We conclude that these lakes are not good breeding habitat for this species. The Madagascar Pochard's persistence here and not at other sites is probably due to a lack of the human-induced habitat degradation that has impacted many other wetlands in Madagascar.

\section{Résumé}

Un des oiseaux les plus rares au monde, le Fuligule de Madagascar Aythya innotata a été considéré probablement être éteint jusqu'à la découverte d'une petite population en 2006. Peu d'information est connue sur ce canard plongeur étant donné que très peu d'études ont été faites avant son déclin et jusqu'à sa disparition. Sa redécouverte a pu donner l'opportunité d'étudier cette espèce à l'état sauvage et d'évaluer la viabilité de cette dernière population. C'est une très petite population présentant des fluctuations aux environs de 25 individus, et utilise principalement deux petits lacs volcaniques dans l'extrême nord de Madagascar. La nidification a lieu seulement dans un de ces lacs, Matsaborimena. Le succès de nidification ( $76 \%$ en $2007-2008)$ et d'éclosion $(89 \%$ en $2007-$ 2008) sont très élevé par rapport aux autres espèces $\mathrm{d}^{\prime} A y t h y a$, mais le succès d'envol de caneton (4\% en 2011-2012) est extrêmement faible. Le pic de taux de mortalité de caneton est à l'âge de 14-21 jours. Nous proposons que l'insuffisance alimentaire soit la principale cause de mortalité de caneton. L'examen des échantillons de matières fécales et de l'analyse isotope stable des plumes et des produits alimentaires potentiels montrent que les adultes sont entièrement insectivores dont les trichoptères constituent apparemment les aliments préférés. Les études sur l'habitat montrent 
que la densité des invertébrés benthiques dans le lac est faible. Les adultes passent $38 \%$ de leur temps journalier à la recherche de nourriture dans les parties peu profonds du lac. Cependant, Matsaborimena présente des bords abrupts et n'a pas de zones peu profondes qui seraient appropriés pour les canetons de plonger à se nourrir. Nous concluons que ces lacs ne sont pas un bon habitat de reproduction pour le Fuligule. La persistance des fuligules dans ces lacs et son absence dans les autres sites, est probablement due à l'absence de dégradation de l'habitat d'origine anthropique dont que de nombreuses les autres milieux humides à Madagascar ont fait l'objet.

\section{Introduction}

The Madagascar Pochard Aythya innotata has a strong claim at present to being the rarest bird in the world. Once common, at least locally, its decline was rapid and largely unnoticed (Young and Kear 2006). With few confirmed records in the second half of the $20^{\text {th }}$ century, the pochard was regarded as extinct (Young and Kear 2006) until rediscovered in 2006 (René de Roland et al. 2007). Little is known about the species as its decline and disappearance occurred before any serious study of Madagascar's wildfowl had been undertaken (Young et al. 2013).

The Madagascar Pochard was overlooked by most of the early European travellers to Madagascar who assumed it to be Ferruginous Duck A. nyroca (Milne-Edwards and Grandidier 1879). Even after its description as a species endemic to Madagascar - in 1894 from a museum specimen of uncertain origin - little information was recorded. Nearly all sightings from the late $19^{\text {th }}$ and early $20^{\text {th }}$ centuries were from one location, Lake Alaotra, and this was the only location at which there were repeat sightings (Young and Kear 2006; see Fig. I). Most sightings simply recorded the presence of pochards and made no mention of habits or numbers. Milne-Edwards and Grandidier (1879) noted that the species was 'apparently uncommon' in Madagascar, but an expedition in 1929 found it was common at Alaotra (Rand 1936).

Alaotra (c.750 m asl) is the largest lake in Madagascar and is surrounded by an even larger area of marsh (Andrianandrasana et al. 2005). It has suffered intense anthropogenic change in the past century, most notably clearance of the marsh for rice cultivation, deforestation of the watershed, the introduction of exotic fish species such as common carp Cyprinus carpio and various tilapia species (Oreochromis, Sarotherodon and Tilapia spp.) and intensive fishing (Pidgeon 1996, Mutschler 2003, Andrianandrasana et al. 2005). These changes have had a devastating effect on the wildlife of the lake, contributing to the extinction of the Alaotra Grebe Tachybaptus rufolavatus (Hawkins et al. 200o), and the local extinctions of the Whitebacked Duck Thalassornis leuconotus (Young et al. 2006) and the pochard. The last confirmed sighting of a pochard at Alaotra was in 1960 (Young and Kear 2006). Following an intense survey and publicity campaign (Wilmé 1994) a local fisherman captured an adult male in 1991 (which died a year later in captivity) but renewed survey efforts failed to detect any further sign of the species (Pidgeon 1996) and by 2006 the pochard was regarded as extinct. Shortly after this, a population was discovered on a small lake in the far north of Madagascar, more than $300 \mathrm{~km}$ from Alaotra (René de Roland et al. 2007). Further surveys have failed to locate any other populations.

The Madagascar Pochard belongs to a clade within the genus Aythya (Livezey 1996, Sorenson and Fleischer 1996) consisting of four species often called 'white-eyes' due to the white iris of adult males. As a group, white-eyes are in trouble: two species, the Madagascar Pochard and East Asian Baer's Pochard A. baeri, are 'Critically Endangered' and the European Ferruginous Duck is 'Near Threatened', leaving the Australian Hardhead A. australis as the only non-threatened species (IUCN 2013). None has been studied in any detail, making the use of sibling species as a guide to the ecology and conservation of the endangered species problematic. Other Aythya species are unspecialised diving ducks: they have a diet of invertebrates and plants, nest in marshes or on small islands and have a preference for water a few metres deep or shallower, with plenty of 


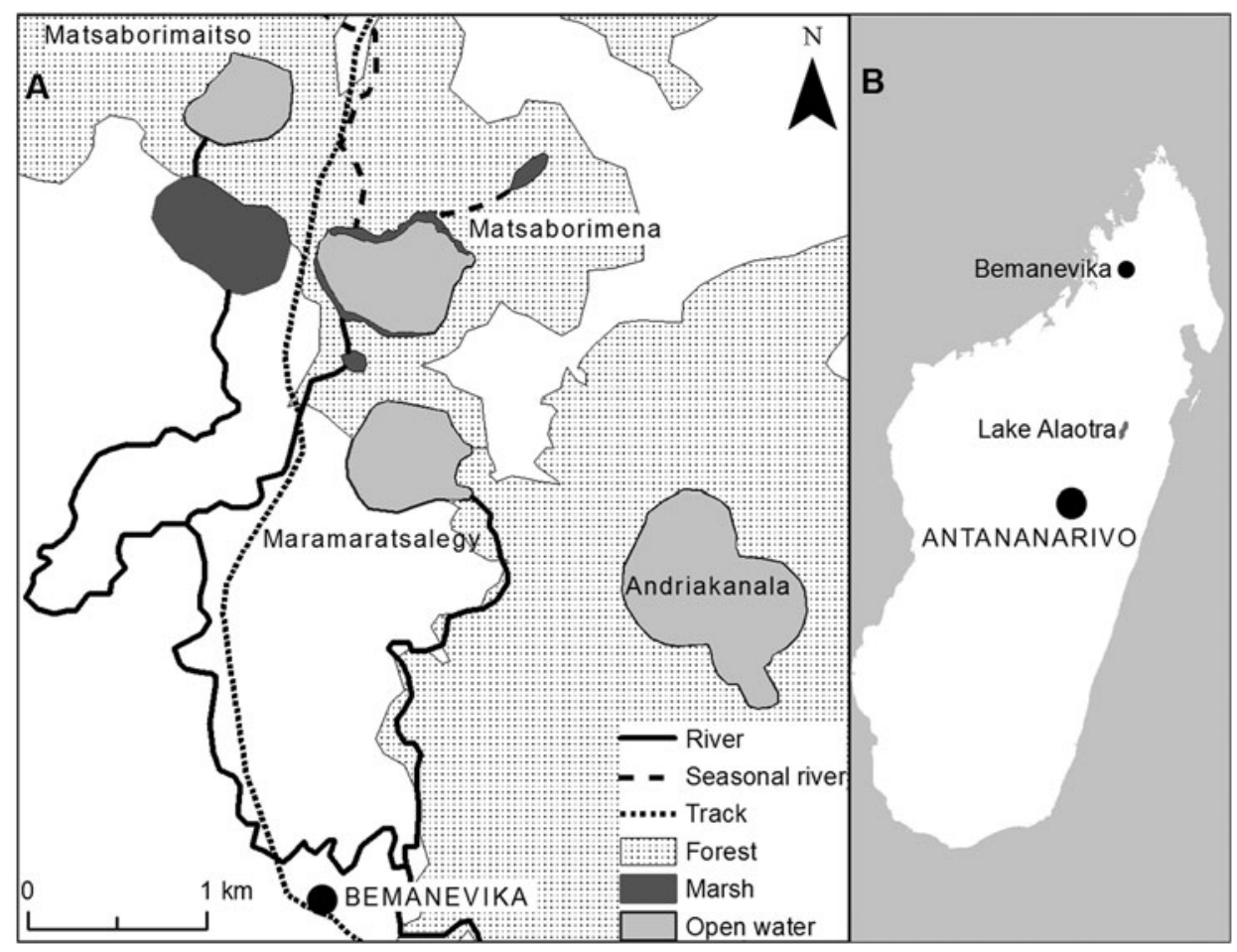

Figure 1. A) Map of the four lakes at the Madagascar Pochard site near Bemanevika, B) Location of Bemanevika and Lake Alaotra.

emergent vegetation (Kear 2005). However, there is some recent evidence that white-eyes may be more specialised in habitat requirements, with Ferruginous Duck being more selective in wetland sites than Common Pochard A. ferina, favouring shallower water, greater vegetation cover and a mosaic habitat structure rather than open water (Petkov 2012). The rediscovery of the Madagascar Pochard provides the first opportunity to study this species. We present data on population size, breeding success, activity budgets and diet, and draw conclusions about implications for species conservation.

\section{Site description}

Madagascar Pochard was rediscovered in the area close to the village of Bemanevika ( $14^{\circ} 20.5^{\prime} \mathrm{S}$, $48^{\circ} 35 \cdot 4^{\prime} \mathrm{E}$ ), located $40 \mathrm{~km}$ north of Bealanana in northern Madagascar (Fig. I). Near the village are four smallish lakes (the largest, Andriakanala, has a surface area of 70 ha and the smallest, Matsaborimaitso, of 22 ha) and areas of marsh (Fig. I; see Rabearivony et al. 2010 for more detail on the area). The lakes are c.1,60o $\mathrm{m}$ asl and have a correspondingly cool climate. Temperatures are generally between 10 and $30^{\circ} \mathrm{C}$, but during the coldest month (July) night-time temperatures can be as low as freezing. Annual precipitation ranges from 1,600 to 2,700 mm. The rainy season extends from November to May, with most rain falling in January-March. Large areas of fragmented forest remain in the landscape. The four lakes are crater lakes with small watersheds, although one lake, Matsaborimena, has two small, seasonal rivers feeding into it and thus a slightly larger watershed. Matsaborimena has a narrow fringe of marsh and emergent aquatic vegetation, consisting mainly of papyrus Cyperus madagascariensis and Eleocharis (Cyperacae) plus other sedges and ferns. At the other lakes there is forest to the water's edge. 


\section{Methods}

\section{Population size and breeding success}

Counts and observations of pochards at Matsaborimena were made by telescope from raised platforms constructed in the marsh to allow a clear view of the lake. Population size was determined by simultaneous counts at all four lakes, conducted monthly from January 2010 to December 2012. Nests were monitored in May-October 2007 and July-August 2008. The approximate location of a nest was determined by watching pochard pairs close to the emergent vegetation; areas where nests were suspected were searched from an inflatable boat. Once found, nests were visited every two days to monitor egg-laying and determine when incubation began. Visits occurred only when it was determined that the female was not present. Once incubation had started, the nest was left undisturbed for three weeks before systematic visits were resumed, again every two days, and continued until hatching. Brood monitoring to assess chick development and fledging success took place in 2011 and 2012. Brood monitoring started in July 2011 and continued until all chicks had fledged or died (February 2012). As there was already a brood present on the lake when observations began in July 2011, brood monitoring was started in May 2012 and again continued until all chicks had fledged or died (February 2013). Twice per week, or more frequently, an observer spent 5-6 hours counting and aging ducklings. Duckling ages were based on plumage development and body shape (after Evrard 1996). Due to the small number of broods the two parameters, number and age, were sufficient to identify individual broods unambiguously. Broods were counted as fledged when flight was observed.

\section{Activity budgets}

Activity budgets were recorded on Matsaborimena, the only lake with a known permanent pochard presence, and quantified using scan sampling. One observer (covering half the lake) or two (each covering separate halves of the lake) scanned the lake every 30 minutes over a $5-6$ hour period on 5-8 days per month. Data recorded for each visible individual were: group size, behaviour and location. Behaviours were classed as: feeding (diving plus occasional dabbling and including inter-dive intervals), swimming, loafing (resting in or out of the water) or social (preening, aggression, courting or copulating). For individuals that were diving, the time spent underwater ('dive time') was recorded. To record locations, two approaches were used: with two observers, the bearings from observers to group were recorded and triangulation used to give a location; otherwise, the group was assigned to one of five zones that the lake was divided into: near (within c. $20 \mathrm{~m}$ ) the marsh in the north, near the marsh in the south, near east or west shore, or the centre of the lake (> $20 \mathrm{~m}$ from any shore or emergent vegetation). Hence, all behavioural data are assigned to a zone on the lake, and a subset is associated with more specific point-locations.

\section{Diet}

Assessing the diet of diving ducks is difficult because it is not possible to see the bird taking a food item. We utilised alternative methods: a survey of available food items, examination of faecal samples for food remains, and stable isotope analysis of feathers and potential food items. To facilitate collection of faecal samples, temporary wooden platforms were constructed in the water near the marsh areas. The pochards would loaf on these platforms and faecal samples were collected within $1-2$ hours of an individual moving away. Samples were stored in $70 \%$ ethanol. Feathers were collected from these platforms and from natural loafing sites (fallen trees) and nests, air dried and stored in paper envelopes. As several other species made use of loafing sites, feathers and faeces were only collected when species identification was certain. Finally, a survey was undertaken of available benthic food. Every month from October 2011 to December 2012, 20 samples of benthic sediment were collected at random sites across Matsaborimena using a Petite 
Ponar grab dredge (WildCo, Florida, USA) with a sampling area of $0.0231 \mathrm{~m}^{2}$. Sampling locations were recorded using a GPS, the substrate type noted (gravel, sand, silt or clay), and water depth recorded using a hand held echo sounder (Plastimo EchoTest II). Samples were sieved through a $0.5 \mathrm{~mm}$ mesh pond net to remove fine sediment and the remainder material examined for 10 minutes. All invertebrates visible to the naked eye were removed and identified to order level. Additional benthic samples were taken from Matsaborimaitso $(n=5)$ and Andriakanala $(n=10)$. Samples of potential food items (invertebrates and plant material) were air dried and stored in paper envelopes for stable isotope analysis.

\section{Sample analysis}

Faecal samples were examined under a microscope to search for identifiable remains. Samples were added to water and allowed to disaggregate overnight. Three sieves (mesh sizes of $500 \mu \mathrm{m}$, $250 \mu \mathrm{m}$ and $75 \mu \mathrm{m}$ ) were stacked in decreasing mesh size, the sample added to the top sieve and the tower swirled to assist the movement of material. The material in each sieve was examined separately. Samples were spread evenly across a petri dish divided into 45 equal size squares. For each category of identifiable food items, the number of squares in which it was present was recorded.

Feathers and invertebrate and plant samples were analysed for nitrogen $\left(\delta^{15} \mathrm{~N}\right)$ and carbon $\left(\delta^{13} \mathrm{C}\right)$ stable isotope ratios at Iso-Analytical Ltd. (Crewe, UK). Results are reported in delta $(\delta)$ notation relative to international standards (Vienna PeeDee Belemnite for $\mathrm{C}$, atmospheric nitrogen for $\mathrm{N})$ according to the following equation: $\delta \mathrm{X}=\left(\left[\mathrm{R}_{\text {sample }} / \mathrm{R}_{\text {standard }}\right]-1\right) \times 1000$, with $\mathrm{X}$ denoting ${ }^{13} \mathrm{C}$ or ${ }^{15} \mathrm{~N}$, and $\mathrm{R}$ representing the ratio of ${ }^{13} \mathrm{C} /{ }^{12} \mathrm{C}$ or ${ }^{15} \mathrm{~N} /{ }^{14} \mathrm{~N}$ respectively. Nitrogen ratios can demonstrate changes in trophic level, with a change of 2-4 \% typical between trophic levels (Inger and Bearhop 2008), while carbon ratios provide information about the primary producers at the base of the food chain.

\section{Statistical analyses}

Means are shown \pm SD. Location data was plotted in ArcGIS 1o (ESRI 2012). Statistical analyses were carried out in R 2.15.2 (R Project for Statistical Computing 2012). Daily Mortality Rates (DMR) of ducklings were calculated using two approaches: the Mayfield method (Johnson 1979) and a Maximum Likelihood approach utilising Generalised Additive Mixed Models (GAMMs). Mayfield estimates of DMR were calculated separately for different age classes: $1-7$ days, 8-14 days and continuing seven day increments to 49 days. An overall DMR was calculated up to 30 days. GAMMs were implemented in the R package ' $m g c v$ ', with chick identity as a random effect and a smoothing factor applied to chick age (see Post van der Burg et al. 2010 for details of the model used).

For analysis of activity budgets, pochard groups were used as the unit of analysis to avoid pseudoreplication among individuals within the group. To examine factors associated with feeding, binomial regression was used. The response was $I=$ feeding and $\mathrm{o}=$ other activity. Explanatory variables were: lake depth; group location (one of the five zones defined above); calendar year and month; size of group; and proportion of males in group. A backwards stepwise approach was used; the effect of removing variables was assessed using G-ratio tests and nonsignificant variables dropped to leave a minimal adequate model.

To examine factors associated with macroinvertebrate abundance, a linear regression was used. Invertebrate count data was converted into a continuous variable, density, by dividing the total count in each sample by the sampling area. Explanatory variables included were: year and calendar month; water depth; and location on the lake (one of the five zones described above). Again, a backwards step-wise approach to model selection was taken.

To assess habitat selection by feeding pochards, dive locations recorded using triangulation were converted into a presence/absence grid covering the lake surface (cell size $40 \mathrm{x} 40 \mathrm{~m}$ ). 
Cells were scored as $1=$ pochards observed diving and $\mathrm{o}=$ no diving observed and analysed using a binomial regression and a backwards stepwise approach. Explanatory variables included were lake depth, invertebrate density and substrate type, all of which were interpolated from the readings taken during benthos sampling.

\section{Results}

\section{Number of birds}

Shortly after rediscovery, in January 2007, 16 birds were counted. Subsequently, the largest counts each year were: 29 birds in 2010 ( 13 females and 16 males); 29 in 2011 ( 14 females and 15 males); and 21 in 2012 (nine females and 13 males). Most monthly counts were lower and the total count did not show a seasonal pattern. From July to November, pochards were seen only on Matsaborimena. The largest counts always came from Matsaborimena, except in March/April each year when Andriakanala had equal or larger numbers. Matsaborimaitso occasionally had small numbers of pochard (maximum of five). Pochards were never seen on Maramaratsalegy.

\section{Breeding productivity}

All nests and broods were found on Matsaborimena. In 2011 and 2012 broods were seen from early July until February. In 2012, nest building was observed in mid-May. Breeding activity thus takes place in nine months of the year. The number of breeding attempts recorded ( 16 in 2007, I1 in 2010 and 20 in 2012) suggests some pairs must make multiple nesting attempts. Pochards were observed moulting during the short period when no breeding activity was observed (January to April). Moulting, flightless individuals were observed on both Matsaborimena and Andriakanala.

Eleven nests were monitored in 2007 and 10 in 2008. Nests were constructed in the emergent vegetation, specifically in the dense papyrus around the two inflows. Nests, supported by papyrus stems, were built $111 \pm 98 \mathrm{~cm}$ from open water and with the top of the nest $30 \pm 10 \mathrm{~cm}$ above water level. The patches of dense papyrus extend as far as $25 \mathrm{~m}$ back from open water, so the pochards apparently have a preference for proximity to open water. This makes the available nesting habitat essentially linear around the edge of the lake, with approximately $320 \mathrm{~m}$ of dense Cyperus around the northern shore. Mean distance recorded between concurrently active nests was $15 \pm 10 \mathrm{~m}$. Nests were shallow circular bowls $20 \mathrm{~cm}$ in diameter, constructed from dead ferns and grasses and lined with feathers.

Breeding parameters are shown in Table 1 . Unsuccessful nests were either destroyed by rats $(n=2)$, as evidenced by faeces found in the nest, or abandoned $(n=3)$. Incubation lasted $25-27$ days. Twelve broods totalling 57 chicks were seen in 2011 and 20 broods totalling 100 chicks in 2012. Mean brood size at first sighting, generally in the first week after hatching but in the second week for four broods, was $4.9 \pm 2.6$ chicks (range 1-9). Overall fledging success was $1.8 \%$ in 2011 and $6 \%$ in 2012. The seven fledged chicks were from four broods and were aged between 9 and 10 weeks, by which time their plumage was similar to adult females.

Table 1. Breeding parameters for the Madagascar Pochard population at Bemanevika. Clutch size is completed clutch size based on repeated visits and is from only 16 nests as the five nest failures all occurred during egg laying.

\begin{tabular}{lcll}
\hline Parameter & Mean $( \pm \mathrm{SD})$ & Sample size & Years \\
\hline Nest success & $76.2 \%$ & 21 nests & 2007,2008 \\
Clutch size & $8.8 \pm 1.1$ (range 7 -11) & 16 nests & 2007,2008 \\
Hatching success & $88.6 \pm 17.1 \%$ & 16 nests & 2007,2008 \\
Fledging success Raw data & $4.5 \%$ & 157 chicks & 2011,2012 \\
$\quad$ Mayfield estimator & $3.1 \%$ & & \\
\hline
\end{tabular}


The majority of ducklings did not live beyond about three weeks (Fig. 2a). Daily Mortality Rate estimates were similar from the two methods (Fig. 2b). DMR from o-3o days was 0.084 (Mayfield) and 0.074 (Maximum Likelihood). DMRs did not differ between the two years (paired Wilcoxon test, $V=19, P=0.5$ for Mayfield and $T=0.3, \mathrm{df}=157, P=0.7$ for ML) and varied by age, peaking between two and three weeks (Fig. 2b): for Mayfield DMRs, the highest rate (age 14-21 days) was significantly higher than the rate for chicks aged $1-7$ days $(Z=1.99, P=0.02)$ and also for chicks aged 22-35 days $(Z=3.5, P<0.001$ and $Z=2.8, P<0.001$ for weeks 4 and 5 respectively) but not chicks aged 8-14 days $(Z=1.19, P=0.1)$. One dead chick was found (in August 2011) and, in over 600 hours of observation, one chick was observed being taken by a Madagascar Harrier Circus macrosceles (in October 2012). Other than this single incidence of predation, no losses occurred between multiple sightings of a brood on the same day. It is therefore assumed that a high proportion of chick losses occurred overnight. Losses occurred gradually, with usually one or two chicks per brood disappearing in a 24 hour period (maximum of four out of seven). The dead chick was examined and presumed to have starved: aged approximately four weeks, it weighed $107 \mathrm{~g}$ (compared to $203 \pm 18 \mathrm{~g}$ at 25 days for 23 captive chicks) and the stomach and intestines were empty.

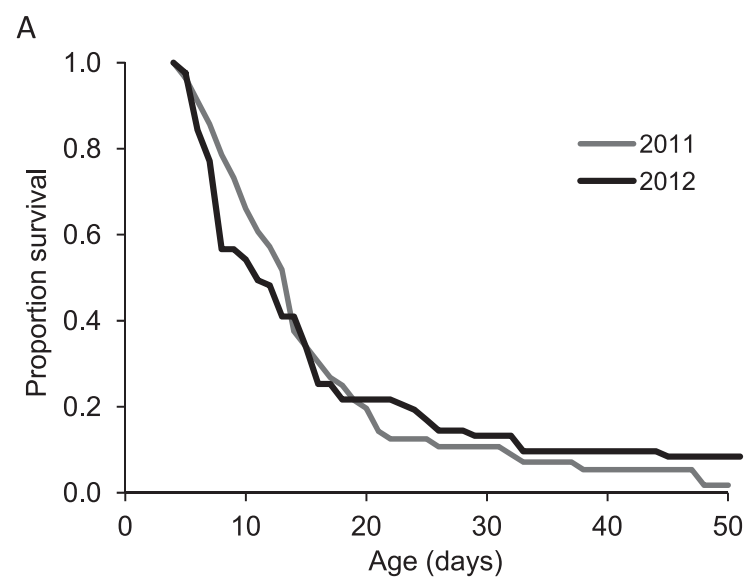

B

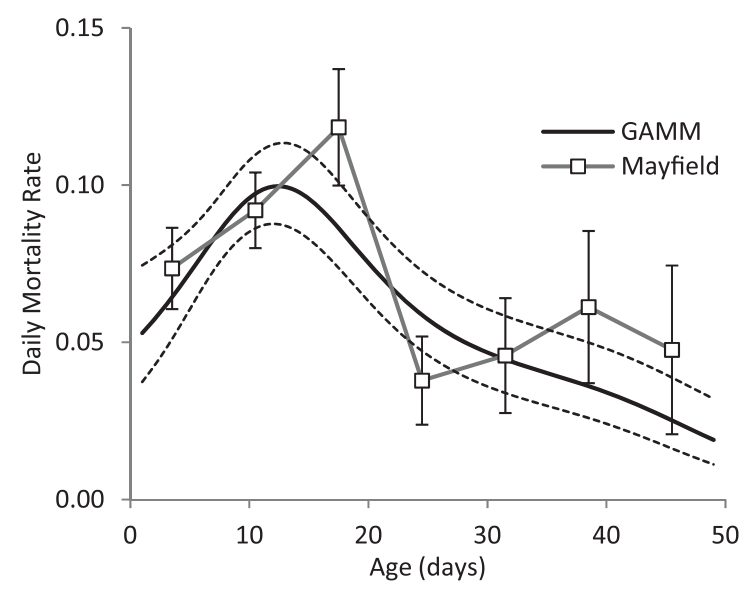

Figure 2. A) Chick survival, B) Daily Mortality Rates (DMR) calculated using the Mayfield method and a Generalised Additive Mixed Model approach, with \pm I SE shown for both methods. 
Other than the seven that fledged, four chicks survived until six weeks of age. Captive chicks are well feathered by six weeks old, but two of these four wild chicks showed no visible signs of juvenile feather growth at this age.

\section{Habitat characteristics}

Maximum depths recorded were: $2.8 \mathrm{~m}$ at Matsaborimena; $14 \mathrm{~m}$ at Matsaborimaitso and $>80 \mathrm{~m}$ at Andriakanala ( $80 \mathrm{~m}$ being the maximum depth recordable with the equipment used). The lakes were steep sided. Matsaborimena has a total surface area of 36 ha, of which c. 7 ha is $>2.5 \mathrm{~m}$ deep, c.11 ha between 2 and $2.5 \mathrm{~m}, \mathrm{c} .14$ ha between 1.5 and $2 \mathrm{~m}$ and c. 3.5 ha between 1 and $1.5 \mathrm{~m}$. This leaves a small area shallower than $1 \mathrm{~m}$, and most of this shallow water is covered with emergent vegetation. Andriakanala was mostly too deep to measure, except a bay in the south of the lake that slopes from shore to $40 \mathrm{~m}$ deep. This bay contains an area (c.0.5 ha) of submerged macrophytes at a depth ranging from 1 to $5 \mathrm{~m}$ and this lake was the only lake with submerged macrophytes. Pochards were observed feeding in this shallow part of Andriakanala, but no data on activity budgets was collected. The benthic substrate was uniform deep, fine silt across all lakes.

\section{Activity budgets}

Adult pochards on Matsaborimena spent $38 \%$ of daylight hours feeding, which was the most common activity recorded. Times devoted to other activities were: $34 \%$ swimming, $24 \%$ loafing ( $8 \%$ out of the water, $16 \%$ in the water) and $3 \%$ on social activities. Adults spent $76 \%$ of their time close to the lake edges and $24 \%$ of time in the lake centre (which comprises c. $65 \%$ of the surface area). There were no differences between calendar months $\left(\mathrm{F}_{5,3605}=6.1, P=0.3\right)$ and no effect of group size $\left(\mathrm{F}_{1,3610}=0.7, \mathrm{P}=0.4\right)$ on the likelihood that a group would be feeding, but adults were significantly more likely to be observed feeding in 2012 compared to 2011 ( $42 \%$ vs. $\left.32 \%, \mathrm{~F}_{1,3611}=59.2, P<0.001\right)$, and in the centre of the lake compared with the edges $(60 \%$ of time in the lake centre spent diving vs. $31 \%$ of time near the edges, $\left.\mathrm{F}_{4,3611}=234, P<0.001\right)$. Groups with proportionally more males in them were less likely to be feeding $\left(\mathrm{F}_{1,3611}=71.7\right.$, $P<0.001$ ). Ducklings were generally not observed diving until c.I4 days old. Prior to this they spent $90 \%$ of the time they were visible (i.e. not hidden amongst the emergent vegetation) feeding at the surface. Mean dive times were $24.5 \pm 3.5$ seconds for adults and $10.1 \pm 2.4$ seconds for chicks.

\section{Diet}

The most numerically common macroinvertebrate orders in the benthic sediment in Matsaborimena (Fig. 3) were Diptera (most specimens were Chironomidae, non-biting midges), Trichoptera (caddis flies), Ephemeroptera (mayflies), and Hemiptera, as well as Hirudinae (leeches). Mean macroinvertebrate density was $457 \pm 467$ individuals $\mathrm{m}^{-2}$. There was no variation in abundance between the five zones of the lake $\left(\mathrm{F}_{5,242}=0.9, P=0.5\right)$ or by depth $\left(\mathrm{F}_{1,246}=1.3, P=0.2\right)$ and little monthly variation except a peak in August-October 2012 (month effect $F_{12,259}=4.2, P<0.001$ ). Matsaborimaitso contained only Diptera (Chironomidae and Chaoboridae, phantom midges). Macroinvertebrates were abundant among the macrophytes in Andriakanala ( $n=5$ grab samples), especially Diptera (Chironomidae), Ephemeroptera and Hemiptera, but less so in the surrounding unvegetated sediment at equal depth (Fig. 3).

In the analysis of dive sites in Matsaborimena, substrate type was invariant. Invertebrate density did not differ between dive sites and non-diving sites $\left(\mathrm{F}_{1,132}=0.01, P=0.9\right)$ but lake depth $\operatorname{did}\left(\mathrm{F}_{1,153}=17.8, P<0.001\right)$ : pochards tended to dive in the shallower parts of the lake (mean depth of diving sites was $1.9 \pm 0.5 \mathrm{~m}$ vs. $2.2 \pm 0.4 \mathrm{~m}$ at non-diving sites).

Fourteen faecal samples were collected. All identifiable material in the samples was of macroinvertebrates; there was no material that was recognisably plant in origin. Chitin fragments were 


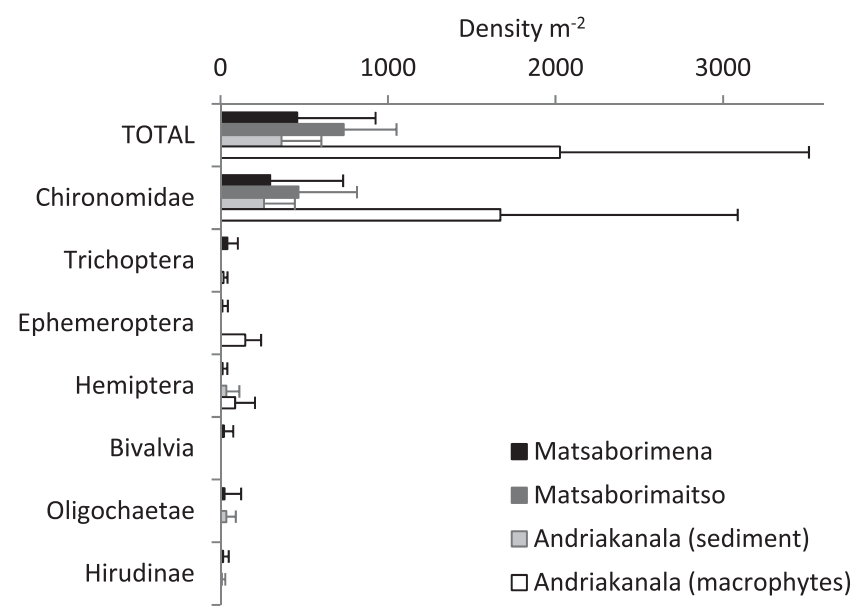

Figure 3. Invertebrate densities in the sediment of three lakes in the Bemanevika area based on grab samples ( $n=280$ for Matsaborimena, 5 for Matsaborimaitso and 10 for Andriakanala). Error bars show \pm 1 SD.

common in all samples; these could have come from any hard bodied invertebrate - most likely Coleoptera (beetles) or Hemiptera - although the abundance of these groups in the diet is difficult to assess as many fragments could come from a single individual. The most frequent order of invertebrates identifiable in the faeces was Trichoptera (Fig. 4). Also identifiable were Odonata (dragonflies) and Hemiptera (specifically Corixidae). Neither Coleoptera nor Odonata were found in the benthos samples, but these groups were common at the surface of Matsaborimena. Only one Chironomidae was observed in the faeces.

Sixteen feathers were collected as well as three invertebrate samples (two Trichoptera and one Chironomidae) and five vegetation samples (two samples of submerged macrophytes from Andriakanala, one of emergent Eleocharis and two of filamentous algae from Matsaborimena). Potential food items were sampled from both Matsaborimena and Andriakanala as moulting

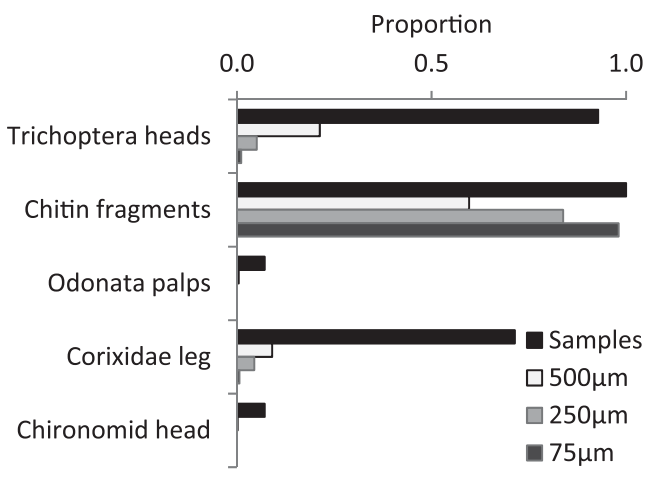

Figure 4. Invertebrate remains in Madagascar pochard faeces. The x-axis shows the proportion of samples $(n=14)$ in which that type of remains were found and among three size fractions, the proportion of cells marked on a Petri dish that contained the type of remains shown after the sample had been spread evenly across the dish. Chitin fragments come from a hard bodied invertebrate, most likely Hemiptera. 
individuals were observed on both lakes. Pochard feathers displayed a narrow range of ${ }^{15} \mathrm{~N}$ content, with a mean of $6.1 \pm 0.5 \%$ (Fig. 5 ). The invertebrate samples had a mean ${ }^{15} \mathrm{~N}$ of $1.84 \%$ and the plants of $0.54 \%$.

\section{Discussion}

The small size and extremely low fledging success recorded in this last population of Madagascar Pochard clearly indicate the perilous situation this species is in. A high duckling mortality rate is the major issue facing this population. High chick mortality is common to many duck species (Kear 2005, Baldassarre and Bolen 2006) but the rate recorded here, 96\% of chicks dying, is extreme. For other species, mortality rates are generally high in newly hatched ducklings and then decline with age (Hill and Ellis 1984, Dawson and Clark 1996, Korschgen et al. 1996, Baldassarre and Bolen 2006); starvation and predation may be the main causes, although determining this is not straightforward (Korschgen et al. 1996, Baldassarre and Bolen 2006). Here we observed a different temporal pattern - an increase in duckling mortality rate after hatching up to a peak between two and three weeks.

Mammalian mesopredators have been responsible for most duckling predation in other studies American mink Neovison vison and fox Vulpes sp. are often the culprits in North America (Baldassarre and Bolen 2006). The closest equivalent in Madagascar, and the only mammalian carnivore known to occur at Bemanevika, is the ring-tailed vontsira Galidia elegans, but this is forest dwelling and not aquatic (Garbutt 1999). The vontsira is also a diurnal predator, yet most duckling disappearances occurred overnight. The only incidence of predation observed in over 600 hours of observation was by Madagascar Harrier, another diurnal species. A likely potential predator is Nile crocodile Crocodylus niloticus, of which one small individual is occasionally sighted in Matsaborimena. The absence of fish in the lakes suggests that waterbirds may form a substantial part of its diet, but infrequent sightings suggest it is not always present. As pochards brood their chicks overnight in a secure location in the marsh, it seems unlikely that the crocodile could be responsible for all of the observed chick mortality. It is also unlikely that a crocodile would target two week old chicks.

The scarcity of predators leaves starvation as a cause of duckling mortality. Circumstantial evidence points that way: slow plumage development compared to captive chicks and the low weight and empty digestive tract of the single dead chick located. The habitat at Matsaborimena may not be ideal for diving ducklings: it is too deep for ducklings to dive and feed, with a low density of invertebrates. Tufted ducklings A. fuligula in water $0.75 \mathrm{~m}$ deep could not meet their

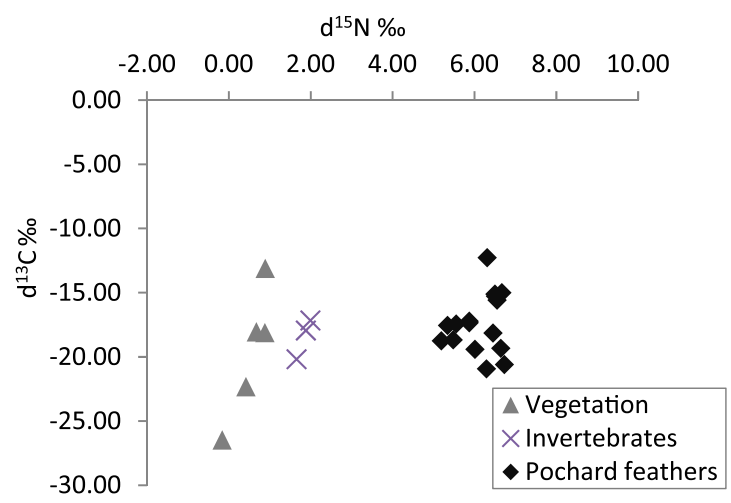

Figure 5. Stable isotope content of Madagascar Pochard feather samples and potential food items collected at two of the four Bemanevika lakes. 
energetic requirements at chironomid densities of 2,000 $\mathrm{m}^{-2}$ (Giles 1990) - four times the mean invertebrate density recorded in Matsaborimena and half the depth. Water depth, which is directly related to the energy required for diving, may be the most important limiting factor in foraging by diving ducks (Lovvorn and Gillingham 1996) - Common Pochards preferred low density food at 1 $\mathrm{m}$ depth over higher density food at 2-3 m (Carbone and Houston 1994). Ducklings cannot dive as deep as adults, reflected in shorter dive times, and even adult pochards stayed in the shallower parts of Matsaborimena when foraging. Ducklings were generally not observed diving until two weeks old, before which they fed at the surface. This switch in foraging method has been observed in other Aythya species and may occur because surface feeding no longer meets ducklings' energetic requirements (Hill and Ellis 1984). The depth of Matsaborimena may mean that two-week old chicks cannot meet energy requirements by diving either, perhaps explaining the peak in mortality.

Despite the problems faced by ducklings, the adults in this population appear healthy: some, if not most, females must have nested twice in 2012 to produce the observed number of broods; the rates of nest and hatching success are high, towards the upper end of records for Aythya species (data in Kear 2005); and the size of the population has been stable since rediscovery, all of which suggest adults in good condition and high adult survival (with low emigration).The Bemanevika population comprises approximately 25 adult birds (11-12 females and $13-14$ males, allowing for the vagaries of counting). We constructed a simple matrix population model - assuming a starting population of 1 f females, average productivity of 0.3 fledged chicks per female per year, equal sex ratio among fledged chicks, initial breeding age of two years (based on observations of captive birds) and no immigration or emigration - which suggests that annual adult survival must be approximately $87 \%$ in order for the population to be stable. This is higher than any published estimates of adult survival in Aythya species, which range from 47-81\% (unpublished database), although the lack of predation in the ecosystem means such high survival may be possible. Although crude, this calculation emphasises how vulnerable and reliant on high adult survival this population is.

Both faecal samples and stable isotope analysis suggest adult Madagascar Pochards have a diet consisting almost entirely of invertebrates. Faecal samples contained no plant remains, only invertebrate remains, and ${ }^{15} \mathrm{~N}$ content increased from the sampled invertebrates to the pochard feathers by $4.2 \%$ - at the upper end of the expected range of fractionation between trophic levels (Inger and Bearhop 2008) - while the increase from the sampled plants to feathers was too large for a single trophic level. Both of these results suggest that plants are a minimal part of the diet. Chironomids were not common in the faeces, despite being the most abundant group in the sediment and having robust and easily identifiable head capsules, suggesting that pochards prefer to eat larger but less abundant Trichoptera and other groups. Other Aythya species consume both plants and invertebrates, with many species' diets biased more to plants (Kear 2005), so an entirely insectivorous member of this genus is unusual.

The invertebrate density in Matsaborimena is apparently enough to maintain adults in good condition, although the time spent feeding on Matsaborimena is higher than for the other whiteeyes for which there are data (Hamilton et al. 2002, Houhamdi and Samraoui 2008). The preference for non-breeding birds to spend time on Andriakanala may be due to the highest invertebrate density of the four lakes, at least in the areas shallow enough for pochards to forage. However, Andriakanala contains only a small area suitable for pochards to feed in and has no nesting habitat.

It seems that the Bemanevika wetlands are not ideal habitat for Madagascar Pochards, or at least not ideal breeding habitat. We suspect that this population was once an unproductive satellite population to larger population(s) elsewhere, either Alaotra or the vast Bealanana wetlands complex located $40 \mathrm{~km}$ south-east of Bemanevika. The Bemanevika population may have become isolated as the main population(s) declined due to the anthropogenic changes outlined in the Introduction, changes which have affected almost all other wetlands in the pochards' historical range. The Bemanevika lakes, in contrast, have remained relatively pristine: they do not contain any fish, native or exotic, and are too deep for rice cultivation. The upper watershed of Matsaborimena is deforested (c.30\% of the watershed area) and is burnt in some years, but the remainder of the watershed is covered in relatively 
pristine forest; Andriakanala and Matsaborimaitso and their small watersheds are almost completely untouched by human disturbance. This appears to be an example of a Critically Endangered species whose last refuge is in habitat that is not ideal, but which is undisturbed.

Management work may improve the habitat for pochards at Bemanevika. Creation of nesting habitat at Andriakanala would be simple enough, perhaps by installing floating rafts, although the small area of feeding habitat available means the lake cannot support many nesting pairs. Boosting the food supply in Matsaborimena would be more difficult. Invertebrate abundance might be boosted by creation of artificial reefs, but creation of shallow areas for ducklings to feed could disrupt the lake and surrounding forest. Supplementary feeding could be used to boost productivity and installing floating rafts would provide a secure location for food to be placed. The diversity of wildlife found at Bemanevika (Rabearivony et al. 2010) means that protecting this important site should be a high priority for conservation in Madagascar. The site has been designated as a temporary protected area under the Malagasy government's 2003 pledge to triple the protected areas in the country and permanent protected status is expected to follow. We do not rule out any management of the pochard population providing this does not disturb the habitat for the other species found there but, even with such management, the small size of the site makes it likely that the pochard population at Bemanevika would never be large. This means that restoration of a larger site(s) elsewhere and (re)introduction of pochards to this new site will be critical for the long term survival of the pochard. For this reason, eggs from three clutches were taken in 2009 and reared in captivity. These birds, three years old at the time of writing, starting breeding in 2011 and the total captive population is 50 birds (Young et al. 2013). The next stage of the project to save this species will involve locating a wetland site that can be restored to a standard where it is able to support a larger population of breeding pochards.

\section{Acknowledgements}

Our gratitude goes to: Rabenosy Médé, who assisted with much of the fieldwork; Loukman Kalavah, Michel Rakotoson and the other Peregrine Fund staff based in Bemanevika for all of their help; Rasolofinirina Andrianarivony ('Nary'), who drove the terrible road to Bemanevika so often; and the villagers at Bemanevika for allowing us onto their land and being so welcoming. The Government of the Sofia Region and Government of Madagascar gave us permission to conduct this work. Steve Brooks, Ian Wallace and Hans Malicky offered advice on invertebrate identifications and sampling methods. Geoff Hilton, Rich Young, Pete Cranswick, Richard Lewis, Glyn Young and Russ Thorstrom have all provided advice and support for the research at Bemanevika. Geoff Hilton also provided detailed comments on the manuscript, as did Steve Goodman and an anonymous referee. Funding for this study came from the BBC Wildlife Fund (project ref.: BBCWF83).

\section{References}

Andrianandrasana, H. T., Randriamahefasoa, J., Durbin, J., Lewis, R. E. and Ratsimbazafy, J. (2005) Participatory ecological monitoring of the Alaotra wetlands in Madagascar. Biodivers. Conserv. 14: 2575-2774.

Baldassarre, G. A. and Bolen, E. G. (2006) Waterfowl ecology and management. $2^{\text {nd }}$ Edition. Florida: Krieger Publishing Company.

Carbone, C. and Houston, A. I. (1994) Patterns in the diving behaviour of the pochard Aythya ferina: a test of an optimality model. Anim. Behav. 48: 457-465.
Dawson, R. D. and Clark, R. G. (1996) Effects of variation in egg size and hatching date on survival of Lesser Scaup Aythya affinis ducklings. Ibis 138: 693-699.

Evrard, J. O. (1996) Accuracy of aging duck broods in the field. J. Field Ornith. 67: $453-455$.

Garbutt, N. (1999) Mammals of Madagascar. New York: Pica Press.

Giles, N. (1990) Effects of increasing larval chironomid densities on the underwater feeding success of downy tufted ducklings Aythya fuligula. Wildfowl 41: 99-106. 
Hamilton, A. J., Taylor, I. R. and Hepworth, G. (2002) Activity budgets of waterfowl (Anatidae) on a waste-stabilisation pond. Emu 102: 171-179.

Hawkins, F., Andriamasimanana, R., Sam, T. S. and Rabeony, Z. (2000) The sad story of the Alaotra grebe Tachybaptus rufolavatus. Bull. Afr. Birding Club 7: 115-117.

Hill, D. A. and Ellis, N. (1984) Survival and age related changes in the foraging behaviour and time budgets of tufted ducklings Aythya fuligula. Ibis 126: 544-550.

Houhamdi, M. and Samraoui, B. (2008) Diurnal and nocturnal behaviour of Ferruginous duck Aythya nyroca at Lac des Oiseaux, northern Algeria. Ardeola 55: 59-69.

Inger, R. and Bearhop, S. (2008) Applications of stable isotope analyses to avian ecology. Ibis 150: 447-461.

IUCN (2013) IUCN Red List of Threatened Species. Version 2013.1. www.iucnredlist. org. Downloaded on 31 July 2013.

Johnson, D. H. (1979) Estimating nest success: the Mayfield method and an alternative. Auk 96: 651-661.

Kear, J., ed. (2005) Ducks, geese and swans. Oxford, UK: Oxford University Press.

Korschgen, C. E., Kenow, K. P., Green, W. L., Johnson, D. H., Samuel, M. D. and Sileo, L. (1996) Survival of radiomarked canvasback ducklings in northwestern Minnesota. J. Wildl. Manage. 60: 120-132.

Livezey, B. C. (1996) A phylogenetic analysis of modern pochards (Anatidae: Aythyini). Auk 113: 74-93.

Lovvorn, J. R. and Gillingham, M. P. (1996) Food dispersion and foraging energetics: a mechanistic synthesis for field studies of avian benthivores. Ecology 77: 435-451.

Milne-Edwards, A. and Grandidier, A. (1879) Histoire physique, naturelle et politique de Madagascar, vol. XII: Histoire naturelle des oiseaux. Paris: Librairie Hachette.

Mutschler, T. (2003) Lac Alaotra. Pp. 15301534 in S. M. Goodman and J. P. Benstead, eds. A natural history of Madagascar. Chicago, USA: University of Chicago Press.

Petkov, N. (2012) Habitat characteristics assessment of the wetlands with breeding Ferruginous duck Aythya nyroca and Pochard A. ferina in Bulgaria. Acrocephalus 32: $127-134$.
Pidgeon, M. (1996) An ecological survey of Lake Alaotra and selected wetlands of central and eastern Madagascar in analysing the demise of the Madagascar Pochard Aythya innotata. Unpubl. report to WWF.

Post van der Burg, M., Powell, L. A. and Tyre, A. J. (2010) Finding the smoothest path to success: model complexity and the consideration of non-linear patterns in nest-survival data. Condor 112: 421-431.

Rabearivony, J., Thorstrom, R., René de Roland, L.-A., Rakotondratsina, M., Andriamalala, T. R. A., Sam, T. S., Razafimanjato, G., Rakotondravony, D., Raselimanana, A. P. and Rakotoson, M. (2010) Protected area surface extension in Madagascar: Do endemisms and threatened species remain useful criteria for site selection? Madagascar Conserv. Dev. 5: $35-47$.

Rand, A. L. (1936) The distribution and habitats of Madagascar birds: summary of the field notes of Mission Zoologique FrancoAnglo-Américaine à Madagascar. Bull. Am. Mus. Nat. Hist. 72: 143-499.

René de Roland, L.-A., Sam, T. S., Rakotondratsina, M. P. H and Thorstrom, R. (2007) Rediscovery of the Madagascar pochard Aythya innotata in northern Madagascar. ABC Bulletin 14: 171-174.

Sorenson, M. D. and Fleischer, R. C. (1996) Multiple independent transpositions of mitochondrial DNA control region sequences to the nucleus. PNAS 93: 15239-15243.

Wilmé, L. (1994) Status, distribution and conservation of two Madagascar bird species endemic to Lake Alaotra: Delacour's grebe Tachybaptus rufolavatus and Madagascar pochard Aythya innotata. Biol. Conserv. 69: 15-21.

Young, H. G. and Kear, J. (2006) The rise and fall of wildfowl of the western Indian ocean and Australasia. Bull. B.O.C. Suppl. 126: 25-39.

Young, H. G., Safford, R., Hawkins, F., Rabarisoa, R and Razafindrajao, F. (2006) Madagascar white-backed duck: what is its true status? TWSG News 15: 38-40.

Young, H. G., Razafindrajao, F. and Lewis, R. E. (2013) Madagascar's wildfowl (Anatidae) in the new millennium. Wildfowl 63: 5-23. 
ANDREW J. BAMFORD*, HANNAH ROBSON

Wildfowl \& Wetlands Trust, Slimbridge, Gloucestershire, GL2 7 BT, UK.

THE SEING SAM, LILY ARISON RENÉ de ROLAND

The Peregrine Fund, BP 4113, Antananarivo 101, Madagascar.

FELIX RAZAFINDRAJAO, LANCE G. WOOLAVER

Durrell Wildlife Conservation Trust, BP 8511, Antananarivo 101, Madagascar.

*Author for correspondence; email: andrew.bamford@wwt.org.uk

Received 4 November 2013; revision accepted 27 February 2014; Published online 26 August 2014 